\title{
THE EFFECT OF HYPERBARIC OXYGEN THERAPY ON THE LEVEL OF LIPID PEROXIDES IN RAT BRAINS
}

\author{
Tadeusz Doboszyński, Bogdan Łokucijewski
}

Department of Maritime and Tropical Medicine WAM, Gdynia, Poland

\section{ABSTRACT}

The problem of oxygen toxicity, and its effect on the nervous system, is an important topic with regard to the application of oxygen and breathing mixes in the pursuit of diving, as well as in the light of the striking synergy between the effects of oxygen and ionising radiation. Studies on the level of lipid peroxides were performed on rat brains. The animals were subjected to exhaustive physical strain in a pressure chamber and oxygen at the pressure between $0-3$ atm for the period of 25-60 minutes. Parallel research was conducted on rested animals. Following the dissection, the brain was homogenised and the levels of lipid peroxides were determined using the Wollman method with TBA. In animals subjected to physical effort over the specified time, no deviations in the levels of lipid peroxides were observed in comparison to the control group. An increase in lipid peroxide level was noted in rats manifesting oxygen toxicity symptoms. On the basis of the above findings, the authors presume that the growth of lipid peroxides in the brain in cases subjected to hyperbaric oxygenation should be recognised as a far-reaching harmful effect of oxygen, occurring after enzymatic damage and the violation of cellular antioxidant protection. At low oxygen overpressures, no deviations in the levels of lipid peroxides were noted as compared to the control group.

Key words: oxygen, overpressure, rat, lipid peroxides.

ARTICLE INFO

PolHypRes 2017 Vol. 57 Issue 1 pp. 63 - 68

ISSN: $1734-7009$ elSSN: 2084-0535

Original article

DOI: $10.1515 /$ phr-2017-0032

Pages: 6, figures: 0 , tables: 1

Originally published in Medical Overview nr 31966

page www of the periodical: www.phr.net.pl Acceptance for print inPHR 30-09-2016

Publisher

Polish Hyperbaric Medicine and Technology Society 


\section{INTRODUCTION}

Works concerned with the harmful effect of oxygen have been present in literature since the classical experiments performed by P. Bert [1878], who proved that an exposure to non-physiologically increased oxygen pressure causes irreversible damage to living matter [7].

Although the limitations imposed on higher forms of life in an atmosphere with an oxygen deficit are well recognised, we are still not always able to answer the question regarding the extent to which an increase in oxygen partial pressure should be considered harmful $[2,6]$. The problem of oxygen toxicity has gained particular importance in relation to the production of artificial atmospheres in underwater research and space flights, as well as in terms of a striking synergism between the effect of oxygen and ionising radiation [7]. The practical scope of interest in hyperbaric oxygenation reaches much further as there have been successful attempts in the application of hyperbaric oxygen therapy in surgery, acute vascular failure, CO poisoning and other cases [4].

Therefore, in recent years we may note an increase in the interest of lipid peroxides and their effect on biological systems [1,11]. It has been observed that lipid peroxides inactivate numerous enzymes, and many researchers have shown that lipid peroxides can be partially responsible for the effect of radiation damage [1]. Experiments on animals confirmed the possibility of an occurrence of lipid peroxides in the brain as a result of several-hours of exposure to oxygen at a pressure increased by several atmospheres [1].

The objective of our study was to examine whether it is necessary to take into account an occurrence of lipid peroxides in the brains' of animals which are kept in conditions of oxygen overpressure for a shorter period of time, but which have performed exhaustive work which, as we know, has a significant influence on an earlier occurrence of oxygen toxicity symptoms in humans $[5,13,14]$.

\section{MATERIAL AND METHODS}

The experiments were conducted in an experimental hyperbaric chamber for small animals on hooded rats with the weight between 180-220 g. The studies were carried out on 49 rats which were divided into 6 groups of 7 to 11 animals. The animals from groups unburdened with effort were placed in the chamber in small cages, whereas the rest swam in water contained within the chamber and heated to $23^{\circ}-24^{\circ} \mathrm{C}$. Once the rats were in place, oxygen with $99 \%$ purity was introduced into the chamber (after purging the chamber of air from a cylinder of suitable pressure, ensuring chamber ventilation of approximately $10 \mathrm{l} /$ minute.

After the intended time elapsed, or in the case of the swimming animals, when they no longer managed to remain at the surface, the pressure in the chamber was reduced. The animals were brought out and put to death by breaking the continuity of the spinal cord at the height of the second cervical vertebra. The brain was immediately dissected and subjected to an analysis on the basis of a method prepared by Wollman [1] with the use of 2-thiobarbituric acid (TBA) [12,3]. A weighed brain was homogenised for 3 minutes at a temperature of $0^{\circ} \mathrm{C}$ with water added at a 1:3 proportion. Next, $3 \mathrm{ml}$ of homogenate was sampled and transferred into a centrifuge tube containing $4.5 \mathrm{ml}$ of $10 \%$ trichloroacetic acid.

The content was shaken and centrifuged. Following the centrifugation, $3 \mathrm{ml}$ of the solution was sampled and transferred into a tube containing $1 \mathrm{ml}$ of $0.75 \% 2$-thiobarbituric acid solution. The tube was placed in a water bath maintained at a temperature of $100^{\circ} \mathrm{C}$ for a period of 15 minutes. The control sample was performed concurrently. Quantification was performed with the use of a Pulfrich photometer using a S-53 filter in F-4992 tray. The obtained results are presented in table 1. 


\begin{tabular}{|c|c|c|c|c|c|c|}
\hline Group & $\begin{array}{l}\text { Experimental } \\
\text { conditions }\end{array}$ & $\begin{array}{l}\text { Number of } \\
\text { determinations }\end{array}$ & $\begin{array}{l}\text { Arithmetic mean } \\
\text { of reading }(\dot{\mathrm{x}})\end{array}$ & $\begin{array}{l}\text { Standard } \\
\mathrm{E}(\dot{\mathrm{x}})\end{array}$ & error & $\begin{array}{l}\text { T calculation } \\
\text { from Student } \\
\text { formula for the } \\
\text { examined } \\
\text { control group in } \\
\text { relation to trom } \\
\text { table }\end{array}$ \\
\hline I & $\begin{array}{ll}\text { Air } & \text { at } \\
\text { atmospheric } & \\
\text { pressure } & - \\
\text { control group } & \\
\end{array}$ & 11 & 0.259 & 0.0179 & & - \\
\hline II & $\begin{array}{lr}\text { Oxygen } 1 & \text { atm - } \\
\text { physical } & \text { strain } \\
\text { below } & 60 \\
\text { minutes } & \\
\end{array}$ & 7 & 0.283 & 0.0186 & & $1.048<t$ \\
\hline III & $\begin{array}{lr}\text { Oxygen } 2 & \text { atm - } \\
\text { physical } & \text { strain } \\
\text { below } & 35 \\
\text { minutes } & \\
\end{array}$ & 8 & 0.292 & 0.0270 & & $1.09<\mathrm{t}$ \\
\hline IV & $\begin{array}{lr}\text { Oxygen } 3 & \text { atm - } \\
\text { physical } & \text { strain } \\
\text { below } & 25 \\
\text { minutes } & \\
\end{array}$ & 8 & 0.281 & 0.0146 & & $1.112<t$ \\
\hline V & $\begin{array}{l}\text { Oxygen } 3 \text { atm - } \\
\text { rest below } 25 \\
\text { minutes }\end{array}$ & 7 & 0.296 & 0.0179 & & $1.654<t$ \\
\hline VI & $\begin{array}{l}\text { Oxygen } 3 \text { atm - } \\
\text { rest below } 4 \\
\text { hours }\end{array}$ & 8 & 0.492 & 0.0302 & & $7.06>t$ \\
\hline
\end{tabular}

\section{DISCUSSION OF RESULTS}

The results were presented with extinction coefficients as arithmetic means of the readings. The highest value was obtained for group VI with animals exposed to oxygen at a pressure of $3 \mathrm{~atm}$ for a period of approximately 4 hours. The results of the remaining groups were approximate, however with quite a considerable dispersion within each group as indicated by the calculated standard error.

It can be assumed that such deviations could be treated as a mistake in the methodology, as a significant effect on lipid peroxides content in the analysed sample was noted even with slight changes in such parameters as time and temperature, both before and during homogenisation. The $t$ values calculated from the Student formula for the group when considered in relation to the control group, i.e. the first group, after their comparison with the tables [9], indicate statistical significance with $\mathrm{p}=0.05$ only with regard to group six. In the case of the remaining groups statistical significance was not noted.

\section{DISCUSSION}

The level of lipid peroxides was determined with the use of a colorimetric reaction with TBC which is an exponent of the presence of malondialdehyde in the researched material. Since the above reaction course, in relation to tissue homogenate, may raise additional reservations due to its incomplete specificity, it should be stressed that the results of research on mitochondria, microsomes and effusion cells available in literature pointed to an existing correlation between the results for the sample with TBA and other indicative lipid oxidation samples [3].

Based on a positive evaluation of the discussed reaction in reference to biochemical studies, we decided to apply it in the evaluation of the level of lipid peroxides in rat brains - the standardisation of sample performance reducing the negative effect of time and temperature.

In order to verify whether lipid peroxides are generated in conditions conducive to the development of an earlier oxygen toxicity, i.e. exhaustive effort (groups II, III, IV), besides the control group which was not subject to hyperbaric oxygenation, we introduced two more groups (V, VI) with animals at rest. In the groups of animals burdened with effort, overall efficiency of the system visibly decreased along with an increasing oxygen overpressure, which was manifested through a shortened endurance when swimming.

Nonetheless, both at the pressure of 2 atm (in two cases) and $3 \mathrm{~atm}$ (in one case) we observed oxygen toxicity symptoms in the form of convulsions. In the group of animals at rest, oxygen toxicity symptoms were not noted during a 25 minute exposure to a pressure of $3 \mathrm{~atm}$. However, when it comes to the group of animals remaining in similar conditions for periods of up to 4 hours, the symptoms of oxygen toxicity were noted in all animals, in some upon the lapse of 2 hours.

Elevated values for lipid peroxides in the brain were obtained only in this group. From the presented data, it results that an occurrence of lipid peroxides in the 
brain, in amounts presentable with the applied method, occurs only in the case of oxygen toxicity that lasts for longer durations, whereas visible symptoms are not detectable in the first period of a short exposure. An increased lipid peroxides content was not noted in the brains of animals subjected to exhaustive physical strain (this regime automatically shortening the exposure).

Although the mechanism of the action of oxygen toxicity on brain tissue is not clear [10], we may presume that one or several factors have a significant impact. Certainly the direct toxic effect of high oxygen partial pressures on particular components of brain cells can be of fundamental meaning. This impact should be connected with the disturbance of essential cellular oxidation processes.

The most general explanation of such disorders highlights that enzymes may be subject to irreversible oxidation in which oxygen plays the role of electron acceptor $[2,8]$. At the same time, attention is paid to the paramagnetic properties of oxygen which in connection to its excess, or lack, may affect electron movement in adjacent parts of the respiratory chain, thus threatening the regular functions of the multienzyme system.
For this reason, hyperoxia or hypoxia affect the opposite ends of the respiratory chain [2]. Hence, it seems that the growth of lipid peroxides in the brain, in the case of hyperbaric oxygenation, should be recognised as a farreaching harmful effect of oxygen, occurring after enzymatic damage and violation of cellular antioxidant protection. In animals subjected to exhaustive effort, with a reduced exposure time, the level of lipid peroxides in the brain did not increase.

\section{Conclusions}

1. In rats' subject to hyperbaric oxygenation at 1-3 atm $\mathrm{O}_{2}$, under physical strain until complete exhaustion was achieved, an increase in lipid peroxides in the brain was not observed.

2. An elevated level of lipid peroxides in the brain was confirmed in rats subjected to a prolonged exposure to hyperbaric oxygen of approximately 4 hours at the pressure of $3 \mathrm{~atm} \mathrm{O}_{2}$.

\section{BIBLIOGRAPHY}

Becker N., Galvin J.: Acrospace Medloine. 1962, 33, 985-987;

Beischer D,:"Man's dependence on the earthly atmosphere. Publ. The McMillan Comp. New York. 1962, 166-186;

Bieri J.: Progress in the Chemistry of Fats and other Lipids. Publ. Oxford 1964, v. 7: 2, 247-266

Boerema J.: American Heart Jurnal. 1965, 69, 289-292;

Dolatkowski A.: Collection of works published between1929-1957. D-wo Mar.Woj. Gdynia 1957;

Fenn W.: Boll. Soc. Ital. Biol. Sperim. 1963, 39, 24, 1703-1713;

Froese G.: J. Appl. Physical. 1960, 15, 53-98;

Gerschmun H.: Man's dependence on the earthly atmosphere. Publ. The McMillan Comp. New York 1962, 171-178.

Guilford J.: Basic methods applied in psychology and pedagogy. PWN, Warsaw 1960

Lambertson C., Kough R., Cooper D., Emmel G., Loeschoke M., Schmidt C.: J.Appl. Physiol. 1953, 5, 9, 471-486;

Płacer Z., Wiesielikowa A., Słabochowa E.: Woprosy Pitanja 1964, 6, 30-33;

Sodlacek S.: Nahrung1958,2, 655

Sjostedt S. Biol Neonatorum. 1964, 6, 1-2, 1-7;

Szczupakow W.: Profiłaktika i leczenie kessonnej bolezni. Medgiz 1962. 